\title{
Improved petrographic-coded model and its evaluation to determine a thermal conductivity log
}

\author{
Nina Gegenhuber ${ }^{1} \cdot$ Markus Kienler $^{1}$
}

Received: 9 January 2017/ Accepted: 16 January 2017/Published online: 30 January 2017

(C) The Author(s) 2017. This article is published with open access at Springerlink.com

\begin{abstract}
Thermal conductivity is one of the crucial properties for thermal modelling as well as tunnelling or geological modelling. Available data are mainly from laboratory measurements. Therefore, additional ways, such as correlations with other properties to derive the petrophysical parameter, will be an advantage. The research presented here continues and improves the petrographiccoded model concept with an increased set of data, including a variety of lithologies, and, furthermore, the correlations, including the electrical resistivity. Input parameters are no longer taken from the literature, but are derived directly from measurements. In addition, the results are compared with other published approaches. Results show good correlations with measured data. The comparison with the multi-linear regression method shows acceptable outcome, in contrast to a geometric-mean method, where data scatter. In summary, it can be said that the improved model delivers for both correlation (compressional wave velocity and electrical resistivity with thermal conductivity) positive results.
\end{abstract}

Keywords Thermal conductivity - Model calculations . Magmatic and metamorphic rocks $\cdot$ Log

Nina Gegenhuber

nina.gegenhuber@unileoben.ac.at

1 Department of Applied Geophysics, Montanuniversitaet Leoben, Leoben, Austria

\section{Introduction}

Energy from geothermal resources is considered regenerative and sustainable. Thermal conductivity is one of the crucial properties for thermal modelling as well as tunnelling or geological modelling. It is also important for hydrocarbon maturation processes. Available data are mainly from laboratory measurements, because it is difficult to determine thermal conductivity in a borehole. However, cores are rare, expensive and represent point information only. Therefore, additional ways, such as correlations with other properties (measurable in the borehole by logging) to describe and derive the petrophysical parameter, will be an advantage to provide data cheaper and faster. Hartmann et al. (2005) published, for example, empirical relationships of thermal conductivity and compressional wave velocity, as well as density, taken from laboratory and $\log$ data for shaly sandstones and marls. They also noted that these correlations are valid for local conditions only.

Barry-Macaulay et al. (2013) made laboratory measurements on rocks and soils from the area around Melbourne (Australia) and stated that thermal conductivity varies with the moisture content, density, mineral composition, and particle size. They measured sandstone, siltstone, and basalt samples, and the results showed that thermal conductivity rises with an increase in density in dry conditions. Saturated samples of sandstone and siltstone did not show a correlation between density and thermal conductivity, but for basalt, a linear increase could be observed. These effects were related to anisotropy and mineralogy of the samples.

Abdulagatova et al. (2009) show the dependence of the effective thermal conductivity (ETC) with pressure and temperature. The ETC increases in porous rocks with 
increasing pressure and is high in the pressure area of $1-100 \mathrm{MPa}$. If pressure over $100 \mathrm{MPa}$ is applied, this effect gets weaker due to the bridging of microcracks or a better grain contact. Furthermore, the ETC decreases with rising temperature.

A general relationship between thermal conductivity and density was published by Sundberg et al. (2009) for igneous rocks. They additionally used density logs for the correlation. Oezkahraman et al. (2004) described the derivation of thermal conductivity from p-wave velocity for building rock types. Kukkonen and Peltioniemi (1998) related thermal conductivity, density, magnetic susceptibility, and compressional wave velocity for 2705 different rock types (plutonic rocks, dykes, volcanic rocks, sedimentary, and metamorphic rocks) from Finland. They concluded that there is no general trend between thermal conductivity and other petrophysical properties.

Popov et al. (2003) divided a collection of data into six subcategories, from different silt and sandstone, to limestone and granite as well as gneiss and amphibolite samples. Correlations display again the general trends for thermal conductivity and porosity, electrical resistivity, and permeability. Depending on the rock type, regression curves fit well to the data for porosity and electrical resistivity.

In this paper, improvements and further development of the "petrographic-coded model concept" (Gegenhuber and Schön 2012) for the derivation of a thermal conductivity $\log$ are demonstrated. Therefore, correlations between thermal conductivity and other petrophysical properties, which can be derived with standard logs, such as a sonic or resistivity $\log$, are used. Furthermore, the results are compared with other published works, such as a multilinear regression method (Gạsior and Przelaskowska 2014) and mixing rules (geometric-mean model) for log data (Fuchs 2013). In his Ph.D. Thesis, Fuchs (2013) described the well-log-based determination of rock thermal conductivity with mixing rules in the North German Basin. The main rock types are sandstone and siltstone. In the thesis, three published papers are combined, where the measurements on samples in the laboratory, different mixing rules for thermal conductivity calculation, and a well-log-based prediction of thermal conductivity are discussed. Further equations for the calculation of thermal properties for sedimentary rock are presented by Fuchs et al. (2015) using again the well-log data.

Furthermore, the comparison with a multi-linear regression method, as presented by Gasior and Przelaskowska (2014), is introduced, as verification for our model correlated thermal conductivity log. For the multilinear regression method, other input parameters were used, due to the fact that some of the logs used by Gąsior and Przelaskowska are not available for the used boreholes.

The research presented here continues and improves the petrographic-coded model concept with an increased set of data, including a variety of lithologies, and, furthermore, new correlations, including electrical resistivity. The input parameters are no longer taken from the literature, but are derived directly from measurements. In addition, the results are compared with other published approaches. Data are sorted in the following lithology groups: granite/gneiss, phyllite, mica schist, sandstone, and basalt. In a second step, petrophysical parameters are calculated with respect to the mineral composition out of measured data and the correlations are described with model calculations. Next, the respective models are applied on the log data to determine a fast evaluation of the thermal conductivity in boreholes. Used are, therefore, the elastic wave velocity and specific electrical resistivity due to the fact that these are the standard logs. The last part is the evaluation of the models and the comparison of various approaches to derive a thermal conductivity $\log$.

\section{Methods and samples}

\section{Samples}

Samples are selected from a database available at the Chair of Applied Geophysics (Montanuniversitaet Leoben, Austria). Selected are different lithologies (sedimentary, magmatic, and metamorphic rock types) from Austria. The database contains all measured petrophysical data from the last couple of years, including geothermal projects. The lithologies used are granite and gneiss, phyllite, various mica schist samples and sandstone as well as basalt. Details and data can be found in the "Appendix".

For the derivation and testing of the model concept on log data and the comparison with other approaches, data from the continental deep drilling project (KTB) in Germany are used. These are available online (http://wwwicdp.icdp-online.org/sites/ktb/welcome.html).

\section{Laboratory measurements}

\section{Thermal conductivity}

Thermal conductivity relates the heat flow density $q$ and the temperature gradient grad $T$. The SI unit is $\mathrm{Wm}^{-1} \mathrm{~K}^{-1}$. Igneous rocks show high thermal conductivity for acid or felsic and lower values for basic or mafic rocks. In sedimentary rocks, the quartz content is essential. Metamorphic 
rocks can show anisotropy in their thermal conductivity parallel and perpendicular to the schistosity (Schoen 2011). The thermal conductivity is determined with a non-steadystate (transient) method. The thermal conductivity meter TK04 (1990, from TeKa, Berlin) is used for the measurements. As heat source serves, a needle encased in a cylinder (half-spaced line-source). The needle is pressed onto the sample with 15 bar, and a contact agent is used to establish an optimal heat flow. A defined heating power (here $3 \mathrm{Wm}^{-1}$ ) is used. The thermistor in the middle of the needle measures the temperature as a function of time. In the end, a heating cycle is recorded and analysed. To consider an anisotropic effect, the needle is rotated in $45^{\circ}$ steps for each measurement.

\section{Electrical resistivity}

Specific electrical resistivity $\rho(\Omega \mathrm{m})$ and its reverse, the electrical conductivity, are intrinsic material properties. The electrical resistivity of rocks is controlled by the rock type, porosity, fluid type in the pore space, clay content, and metallic content. Most of the rock forming minerals show high resistivity. The resistivity is high in dry rocks, but conductivity rises in water saturated, porous rocks because of electrolytic conductivity and solid fluid interactions (Schoen 2015). To determine the specific electric resistivity, a four-point-light instrument (Type: LF 325 from WTW, Germany) is used.

\section{Compressional wave velocity}

Compressional wave velocity $\left(v_{\mathrm{p}}\right)$ is described with bulk modulus $k$, the shear modulus $\mu$, and the bulk density $\rho$. The SI unit is $\mathrm{ms}^{-1}$. Wave velocity is related to the solid rock skeleton, the pore volume and cracks, the grain contact, pressure and temperature, the fluid saturation, and the type of pore filling. If the porosity increases, the velocity decreases. In metamorphic rocks, anisotropy can be recognized. Igneous rocks show an increase in velocity from acid to basic minerals. The velocity in sedimentary rocks is influenced by porosity the most (Schoen 2015). The compressional wave velocity is determined with a bench-top ultrasonic device (main parts from 2012). The plug (diameter $=1$ inch) is fixed in the device at a pressure of 5 bar. A transmitter produces a mechanical pulse, moving through the sample and recorded at the receiver. To get a good contact between the sample and the transmitters, a contact agent is used. The measured signals are recorded and saved on the computer. To pick the first arrivals and calculate the velocity, a self-written program with MATLab is applied (Gegenhuber and SteinerLuckabauer 2012).

\section{The models used for correlations and derivation of the solid parameters}

Thermal conductivity depends mainly on mineral composition and porosity or fractures. In this study, laboratory data are described with three equation types to find correlations between thermal conductivity and compressional wave velocity as well as resistivity. To link the matrix and fluid properties, the inclusion model after Budiansky and O'Connell (1976) (elastic properties) and Clausius-Mossotti model (Berryman 1995) (thermal properties) is used. To calculate the formation factor (resistivity), the Archie' equations (Archie 1942) are applied. The following paragraphs describe that the three model types are used. These models are used, because first results showed good fit with the data.

The Archie equation, derived from experimental data, combines the cementation factor $m(-)$, the resistivity of the formation $R_{0}(\Omega \mathrm{m})$, the effective porosity $\Phi(-)$, the resistivity of water $R_{\mathrm{w}}(\Omega \mathrm{m})$, and the formation factor $F(-)$

$F=\frac{1}{\Phi^{\mathrm{m}}}=\frac{R_{0}}{R_{\mathrm{w}}}$

Samples with a low cementation factor show flat or jointed pores. Spherical pores show a higher cementation factor. The formation factor $(F)$ is independent of the rock type (all rock building minerals are isolators). Just the shape and the volume of the pore space have an influence on this parameter if the pore space is filled with water and the samples are clay free.

The inclusion model estimates penny-shaped pores, and therefore, Budiansky and O'Connell (1976) developed equations for the elastic properties. The approach assumes high frequencies (ultrasonic laboratory measurements) for saturated rocks and idealizes ellipsoidal inclusions, isotropic, and linear elastic rock matrix, and that cracks are isolated with respect to fluid flow:

$k_{\mathrm{sc}}=k_{\mathrm{s}}\left[1-\frac{16}{9} \frac{1-v_{\mathrm{sc}}^{2}}{1-2 v_{\mathrm{sc}}} \varepsilon\right]$,

$\mu_{\mathrm{sc}}=\mu_{\mathrm{s}}\left[1-\frac{32}{45} \frac{\left(1-v_{\mathrm{sc}}\right)\left(5-v_{\mathrm{sc}}\right)}{2 v_{\mathrm{sc}}} \varepsilon\right]$,

where $k_{\mathrm{sc}}$ is the calculated bulk modulus, $k_{\mathrm{s}}$ is the bulk modulus of the host material, $\mu_{\mathrm{sc}}$ is the calculated shear modulus, and $\mu_{\mathrm{s}}$ is the shear modulus of the host material.

Bulk and shear moduli of the host material are determined from laboratory measurements by plotting the measured bulk or shear modulus versus porosity for each lithology and extrapolating the linear correlation to zero porosity. This method delivers optimal input values for the model calculations: 
$\varepsilon=\left(\frac{\Phi}{\alpha}\right)\left(\frac{3}{4 \pi}\right)$,

where $\varepsilon$ is the crack density parameter, $\alpha$ is the aspect ratio $(\alpha=a / c), a$ and $c$ are axes of ellipsoid, $v_{\mathrm{sc}}$ is the effective Poisson's ratio:

$v_{\mathrm{sc}} \approx v_{\mathrm{s}}\left[1-\frac{16}{9} \varepsilon\right]$,

and $v_{\mathrm{s}}$ is the Poisson ratio of the host material.

To calculate the velocity of the compressional wave $v_{\mathrm{p}}$, also the bulk density $\rho_{\mathrm{b}}$ is needed:

$\rho_{\mathrm{b}}=(1-\Phi) \rho_{\mathrm{s}}+\Phi \rho_{\text {fluid }}$

$v_{\mathrm{p}}=\left(\frac{k_{\mathrm{sc}}+\frac{4}{3} \mu_{\mathrm{sc}}}{\rho_{\mathrm{b}}}\right)^{1 / 2}$,

where $\rho_{\mathrm{s}}$ is the grain density (measured in the laboratory), and $\rho_{\text {fluid }}$ is the density of the fluid.

Thermal conductivity is calculated with the equation of Clausius-Mossotti (Berryman 1995):

$\lambda_{\mathrm{CM}}=\frac{1-2 \Phi R_{\mathrm{mi}}\left(\lambda_{\mathrm{S}}-\lambda_{\mathrm{fl}}\right)}{1+\Phi R_{\mathrm{mi}}\left(\lambda_{\mathrm{S}}-\lambda_{\mathrm{fl}}\right)}$,

$R_{\mathrm{mi}}=\frac{1}{9}\left(\frac{1}{L_{\mathrm{a}, \mathrm{b}, \mathrm{c}} \lambda_{\mathrm{fl}}+\left(1-L_{\mathrm{a}, \mathrm{b}, \mathrm{c}}\right) \lambda_{\mathrm{s}}}\right)$,

where $\lambda_{\mathrm{S}}$ is the thermal conductivity of the matrix, $\lambda_{\mathrm{fl}}$ is the thermal conductivity of the inclusion, and $R_{\mathrm{mi}}$ is the function of depolarization exponents $L_{\mathrm{a}}, L_{\mathrm{b}}$, and $L_{\mathrm{c}}$. In this study, the shape of the pores is idealized as plate-like objects $(a=b \gg c)$. The model assumes randomly arranged inclusions.

The thermal conductivity of the matrix $\lambda_{\mathrm{S}}$ is also determined by plotting thermal conductivity versus effective porosity, and the linear trend is extrapolated to zero porosity. To eliminate the influence of pores, thermal conductivity is modelled for correlations (Clausius-Mossotti) under consideration of different aspect ratios. The experimental data should range between higher and lower aspect ratio.

By summarizing, the following steps are carried out for each lithology:

- Plotting thermal conductivity and bulk/shear modulus of measured data versus porosity for each rock type (petrographic code influence).

- Extrapolating the linear correlation to zero porosity for derivation of the solid host parameters (input values for the model calculations).

- Plotting thermal conductivity versus compressional wave velocity and formation factor for the correlations.

- Data are described with model calculations and different aspect ratios for an optimal result.

- The calculated correlations are described with one equation for the further application on log data.

\section{Models for comparison and evaluation}

Geometric-mean approach (Fuchs 2013)

Lichtenecker (1924) introduced the geometric-mean model and Fuchs (2013) applied this model to calculate matrix and bulk thermal conductivity:

$\lambda_{\mathrm{m}}=\sum_{i=1}^{n} \lambda_{i} V_{i}$

where $\lambda_{\mathrm{m}}$ is the matrix thermal conductivity $\left[\mathrm{Wm}^{-1} \mathrm{~K}^{-1}\right], \lambda_{i}$ is the thermal conductivity each component $\left[\mathrm{Wm}^{-1} \mathrm{~K}^{-1}\right]$, and $V_{i}$ is the volume fraction each component [-].

For this model, the porosity is predicted from the neutron log. The thermal conductivity values for the used minerals are literature values. The KTB provides data from $\mathrm{XRD}$, and therefore, the volume fractions of the main minerals are known. Used minerals are quartz, potassium feldspar, biotite, white mica, amphibolite, chlorite, garnet, and plagioclase.

\section{Multi-linear regression}

The relationships between several independent variables can be analysed with the statistical technique of the multiple regression. Gąsior and Przelaskowska (2014) used empirical models based on the relationship between thermal conductivity and other petrophysical parameters on well-log data from Meso-Paleozoic rocks from Tarnów-Dębica (Poland). They distinguished between siliciclastic and carbonate rocks and a determination coefficient at minimum $>0.74$ indicates the correctness of their models (Gasior and Przelaskowska 2014). The program Interactive Petrophysics (Senergy) allows the user to predict a result curve from different input logs. The curve to predict (in this case thermal conductivity data from the cores) is defined, and these data are used to create the model. With the different input logs, the "new log" will be calculated and the percentage used of each log is given. The input curves are the corrected gamma ray (CGR), the Laterolog deep (LLD), the inverse velocity of the compression wave (DTCO), and the neutron porosity (NPHI).

The derived regression formula is

$$
\begin{aligned}
\lambda= & f\left(V_{\mathrm{p}}, \mathrm{CGR}, \mathrm{LLD}, \mathrm{NPHI}\right), \\
\lambda= & 10(-1.016+0.097 \mathrm{CGR}+0.56 \mathrm{DTCO} \\
& +0.004 \mathrm{LLD}-0.075 \mathrm{NPHI}) .
\end{aligned}
$$

\section{Results}

\section{Laboratory data}

The model calculations are used for five different lithologies. For every lithology, the properties of the host rock are determined by laboratory data and these are the basis for 
Table 1 Overview of the host properties ( $n=$ number of samples for $F=$ formation factor and $v_{\mathrm{p}}=$ compressional wave velocity, $k_{\mathrm{s}}=-$ compressional modulus, $\mu_{\mathrm{s}}=$ shear modulus, $\rho_{\text {matrix }}=$ grain density,

\begin{tabular}{|c|c|c|c|c|c|c|c|}
\hline Rock type & $n\left(F / v_{\mathrm{p}}\right)$ & $k_{\mathrm{s}}(\mathrm{GPa})$ & $\mu_{\mathrm{s}}(\mathrm{GPa})$ & $\rho_{\text {matrix }}\left(\mathrm{g} \mathrm{cm}^{-3}\right)$ & $\lambda_{\mathrm{s}}\left(\mathrm{Wm}^{-1} \mathrm{~K}^{-1}\right)$ & $\alpha$ & $m$ \\
\hline Granite/gneiss & $47 / 25$ & 32 & 29 & 2.74 & 3.4 & 0.1 & 1.3 \\
\hline Phyllite & $61 / 35$ & 56 & 43 & 2.79 & 4 & 0.2 & 1.9 \\
\hline Mica schist & $57 / 25$ & 48 & 38 & 2.77 & 4.3 & 0.02 & 1.3 \\
\hline Sandstone & $33 / 21$ & 43 & 30 & 2.73 & 4.5 & 0.1 & 1.9 \\
\hline Basalt & $17 / 11$ & 84 & 68 & 2.98 & 3.2 & 0.2 & 1.3 \\
\hline
\end{tabular}

the calculations. Table 1 gives an overview of the input data for the inclusion models for different lithologies. The differentiation in the various lithologies and derivation of the input parameter are the petrographic part in the model concept. Detailed interpretation of the lithologies is important to derive excellent results.

Figure 1 shows the results of the correlations between thermal conductivity and compressional wave velocity for different lithologies derived from laboratory data. Points are measured data and lines are calculated with the inclusion models. For each porosity, one value for thermal conductivity is calculated with the inclusion model by Clausius-Mossotti (Berryman 1995) and one value for compressional wave velocity is calculated with the inclusion model by Budiansky and O'Connell (1976). These values are furthermore plotted in Fig. 1 as correlation lines. The result of calculated lines cannot be applied directly. Therefore, trend lines are added to describe the lines and to make the correlations easily applicable in the form of $\lambda=f\left(v_{\mathrm{p}}\right.$ or $\left.F\right)$. These equations can be found in Table 2 .

Granite and gneiss as well as phyllite and mica schist samples can show an anisotropic effect. To make the approach easily applicable, this effect is neglected within the model calculations. Focusing on the singular plots, granite shows better results for the correlation with $v_{\mathrm{p}}$, where there are some outliers for the correlation with resistivity. The higher thermal conductivities are "Fasergneiss" samples and have higher quartz content. The low velocities are an anisotropic effect.

The basalt and diorite show three outliers with higher thermal conductivity because of lower porosity. They are all from the same stone pit.

Data of mica schist and phyllite show a big variation due to anisotropic effects and variations in porosity data as well as mineralogical effects. The anisotropic effect is neglected, because it is rarely analysed in the borehole too.

Sandstone samples show good correlations for both properties and provide highest thermal conductivities. The highest thermal conductivities can be found for quartzite samples, which are outliers for correlation with formation factor. This is may be a result of their low porosity. and $\lambda_{\mathrm{s}}=$ thermal conductivity) and aspect ratios $\alpha$ and cementation factor $m$ for different lithologies

Table 2 summarizes the derived equations for further application on log data. The lines which result from the two models cannot be applied directly on log data; therefore, the resulting correlation lines out of the calculations are additionally described with trend lines, which are presented in Table 2. These equations make the model concept applicable, because the form results in $\lambda=f\left(v_{\mathrm{p}}\right.$ or $\left.F\right)$.

\section{Application on log data}

The following figures will show the results for two selected sections of the continental deep drilling project, one for gneiss and one for metabasite. Shown are various combinations with other approaches to set them all in context to each other. Figure 2 shows the gneiss section. In the middle of the figure, the histograms show the variation of the different approaches, starting in the left upper corner with the measured thermal conductivity of the cores, followed by the geometric-mean model, the multi-linear regression model, and thermal conductivity with the equations presented here for the sonic and the resistivity $\log$. The geometric-mean model delivers a broad variation of thermal conductivity values, possibly because the model is developed for sedimentary rock types. The multi-linear regression model and the models presented here deliver good results and the data do not scatter.

The other figures show various correlations between the five thermal conductivity values. Due to the fact that core data show a broader variation, the comparison with these shows also some scattering. This may be the result of anisotropy within the gneiss samples. Best result is delivered by the model using the sonic log. The mean value delivered by the resistivity log fits well to the core data but does not show such a broad range of data as the cores do. A strong correlation can be observed for the approach using the sonic $\log$ and the multi-linear regression method.

In the same plots for a metabasite section, the core data show no big variation within the set of data and a lower thermal conductivity than the gneiss samples. The geometric mean again scatters too much to deliver a good result. The multi-linear regression delivers good results 
Fig. 1 Plots of $v_{\mathrm{p}}$ and $1 /\left(F^{0.5}\right)$ versus thermal conductivity for the different lithologies: granite/ gneiss, basalt, mica schist, and phyllite; dots are measured data from the laboratory, and lines are the result of calculation of thermal conductivity with the inclusion model by ClausiusMossotti (Berryman 1995) and compressional wave velocity with the inclusion model by Budiansky and O'Connell (1976)

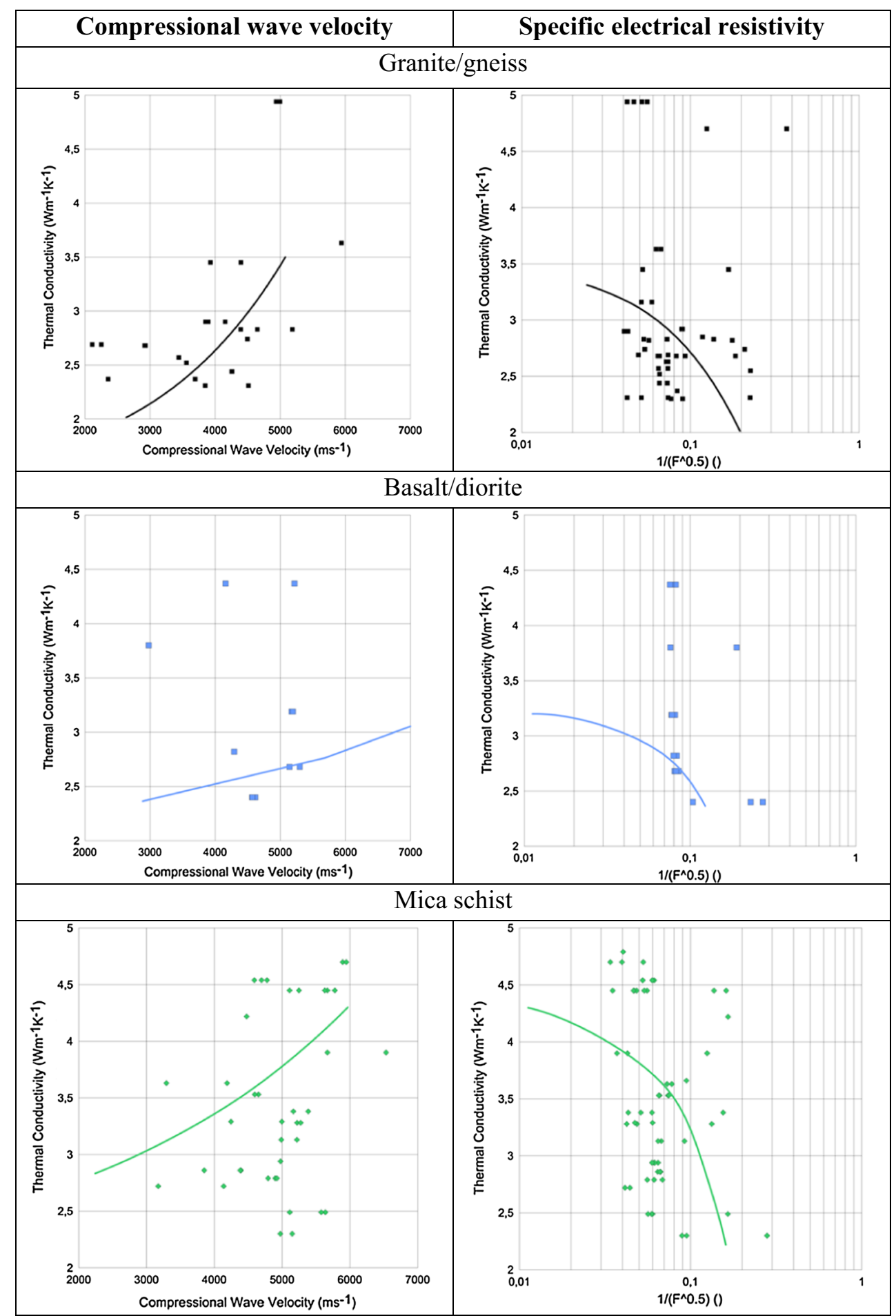

with only a minor overestimation of about $0.5 \mathrm{Wm}^{-1} \mathrm{~K}^{-1}$. Both model concepts also overestimate the core data, data from the sonic log with about $0.5 \mathrm{Wm}^{-1} \mathrm{~K}^{-1}$, and the resistivity $\log$ data with $1 \mathrm{Wm}^{-1} \mathrm{~K}^{-1}$. Here, again, a strong correlation between the approach using the sonic log and the multi-linear regression method can be observed.
Figure 3 shows additionally two log sections (2900-3400: gneiss and 3600-4000: metabasite) with the results in a log plot. The dots in the plots are measured samples. In red is the result with the geometric mean and in black the multi-linear regression approach. The fourth track shows the result for $\lambda$ for basalt from the resistivity (turquoise), $\lambda$ for basalt from the compressional wave velocity 
Fig. 1 continued

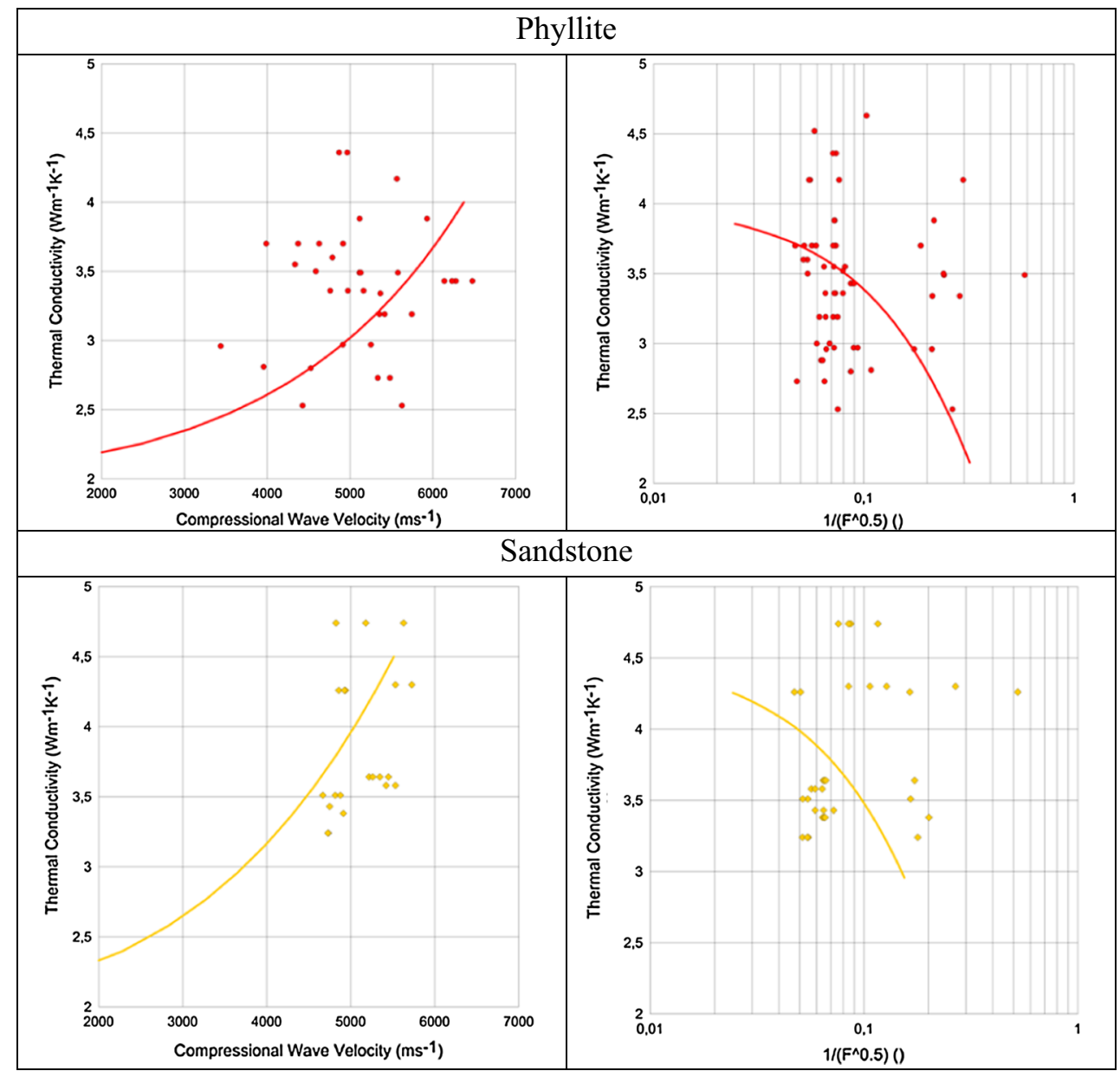

Table 2 Regression equations for a further application on log data derived from the calculated correlation lines [thermal conductivity with the inclusion model by Clausius-Mossotti (Berryman 1995) and

\begin{tabular}{lll}
\hline Rock type & Sonic log & Resistivity log \\
\hline Granite/gneiss & $\lambda=1 \mathrm{E}-07 v_{\mathrm{p}}^{2}-0.0003 v_{\mathrm{p}}+1.98$ & $\lambda=-3.73\left(1 / F^{0.5}\right)^{2}-3.5\left(1 / F^{0.5}\right)+3.59$ \\
Phyllite & $\lambda=9 \mathrm{E}-08 v_{\mathrm{p}}^{2}-0.0003 v_{\mathrm{p}}+2.48$ & $\lambda=-5.85\left(1 / F^{0.5}\right)+3.98$ \\
Mica schist & $\lambda=5 \mathrm{E}-08 v_{\mathrm{p}}^{2}-2 \mathrm{E}-05 v_{\mathrm{p}}+2.63$ & $\lambda=-10.2\left(1 / F^{0.5}\right)^{2}-12.4\left(1 / F^{0.5}\right)+4.5$ \\
Sandstone & $\lambda=1 \mathrm{E}-07 v_{\mathrm{p}}^{2}-0.0003 v_{\mathrm{p}}+2.41$ & $\lambda=5.28\left(1 / F^{0.5}\right)^{2}-10.93\left(1 / F^{0.5}\right)+4.52$ \\
Basalt & $\lambda=2 \mathrm{E}-08 v_{\mathrm{p}}^{2}-1 \mathrm{E}-06 v_{\mathrm{p}}+2.23$ & $\lambda=-4.73\left(1 / F^{0.5}\right)^{2}-7.69\left(1 / F^{0.5}\right)+3.34$
\end{tabular}

(violet), $\lambda$ for gneiss from the resistivity (blue), and $\lambda$ for gneiss from the compressional wave velocity (orange).

\section{Summary and conclusion}

In most drilling projects, sonic log and resistivity log are available. Measuring thermal conductivity in a borehole is difficult and time consuming. Therefore, petrographic- compressional wave velocity with the inclusion model by Budiansky and O'Connell (1976)] 

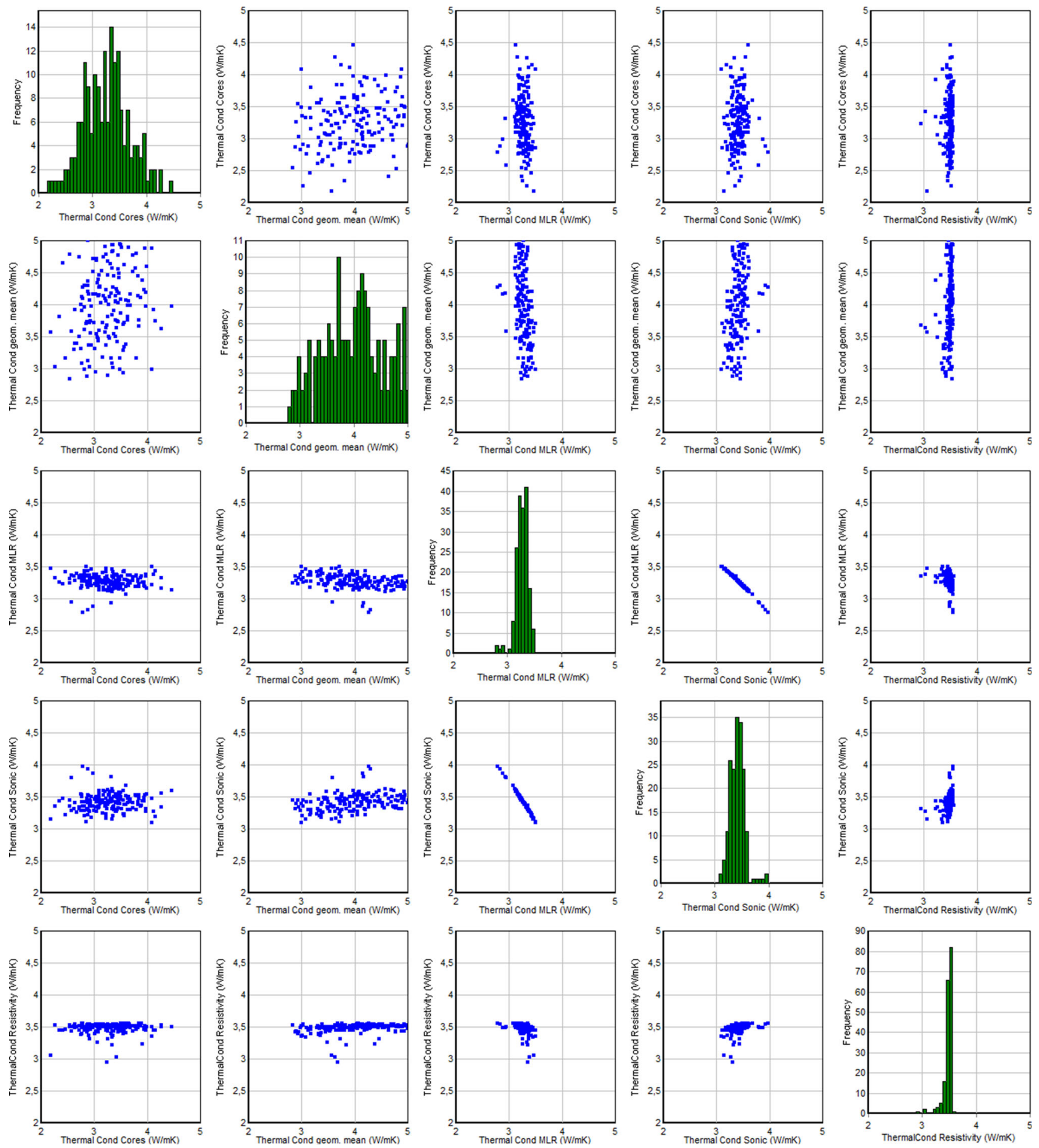

Fig. 2 Thermal conductivity for granite section, thermal conductivity from cores versus the improved derived correlation equations (sonic and resistivity $\log$ ), the multi-linear regression, and the geometric-mean approach. In green are the histogram data for the various approaches

with the laboratory data for the five selected lithologies: granite/gneiss, phyllite, mica schist, basalt/diorite, and sandstone. In the next step, the models for granite/gneiss and basalt are applied on the log data. The sonic log provides the values for the compressional wave velocity and is the basis for the first model estimation. The compressional wave velocity shows a strong correlation with the thermal conductivity, and therefore, the calculated data fits the real data excellent. 


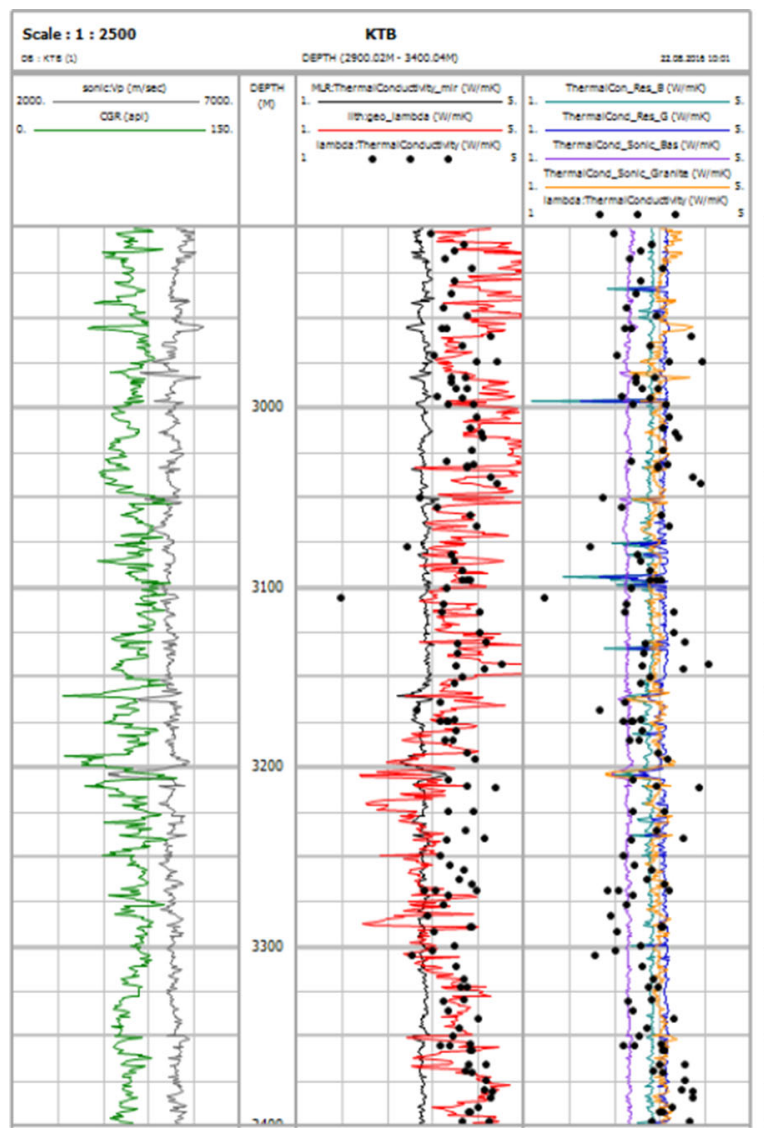

Fig. $3 \mathrm{Log}$ plot for the results of thermal conductivity for 2900-3400 m (gneiss) and 3800-4000 m (metabasite). The first track in both plots shows compressional wave velocity (green) and gammaray (grey), the third track shows multi-linear regression (black) and the geometric mean (red) and plus the measured data

With the resistivity log, the formation factor can be calculated and the second approach can be applied. This model is influenced mostly by the pore shape and their fillings. For the lithology granite/gneiss, it works well, but in the case of basalt, thermal conductivity is slightly overestimated. The calculated models show:

- no depth influence;

- strong correlation with the real data;

- dependence on lithology and pores/fractures (aspect ratio).

The petrographic-coded model concept covers the influence of lithology and delivers good results for the derivation of thermal conductivity with the standard logs (sonic and resistivity $\log$ ). In comparison with other approaches, data do not scatter, such as the geometricmean model. This may result from the fact that the model is developed for sedimentary rock types. The multi-linear regression method shows a strong correlation for both gneiss and metabasite sections with the derived thermal conductivity out of the sonic log. For the presented models,

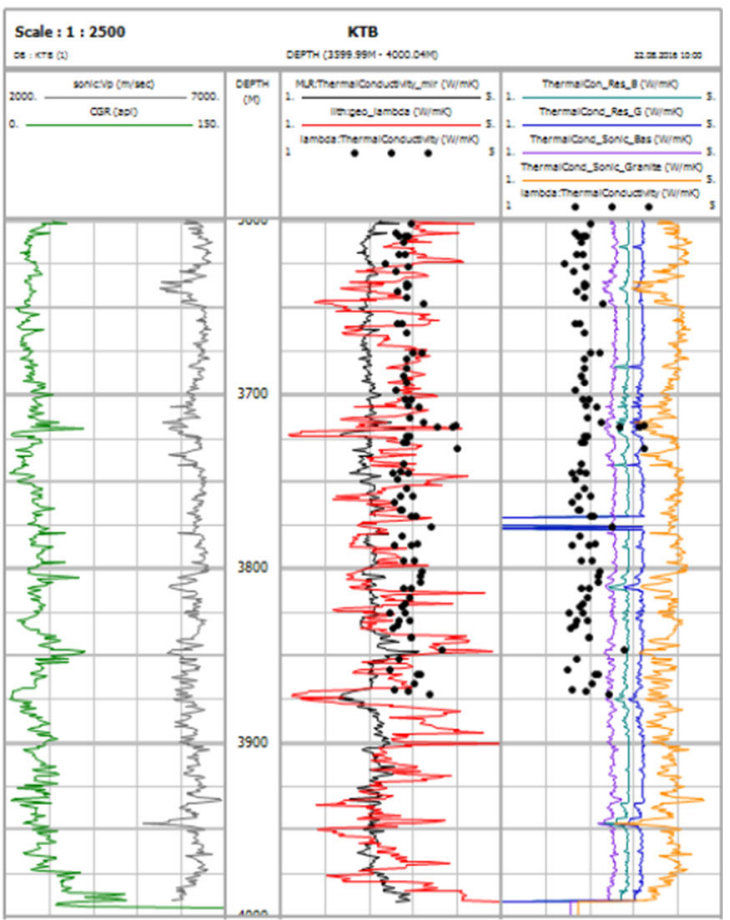

from the samples as dots, the fourth track shows the result for $\lambda$ for basalt from the resistivity (turquoise), $\lambda$ for basalt from the compressional wave velocity (violet), $\lambda$ for gneiss from the resistivity (blue), and $\lambda$ for gneiss from the compressional wave velocity (orange), and the measured $\lambda$ from the samples as dots

only the lithology needs to be known and a sonic or resistivity $\log$ needs to be available. Especially, the sonic $\log$ delivers good results and derived thermal conductivity data can be used for example in geothermal projects. This method is better than using only data from the literature due to the fact that various lithologies can have a broad range of thermal conductivity values.

Acknowledgement Open access funding provided by Montanuniversität Leoben.

Open Access This article is distributed under the terms of the Creative Commons Attribution 4.0 International License (http://crea tivecommons.org/licenses/by/4.0/), which permits unrestricted use, distribution, and reproduction in any medium, provided you give appropriate credit to the original author(s) and the source, provide a link to the Creative Commons license, and indicate if changes were made.

\section{Appendix}

See Table 3. 
Table 3 Data

\begin{tabular}{|c|c|c|c|c|}
\hline Rock type & $\lambda(\mathrm{W} / \mathrm{mK})$ & $v_{\mathrm{p}} \operatorname{dry}(\mathrm{m} / \mathrm{s})$ & $F(-)$ & $\Phi_{\text {eff }}(-)$ \\
\hline Granite/gneiss (rich in biotite) & 2.52 & 3559.7 & 232.60 & 0.126 \\
\hline Gneiss (rich in biotite) & 2.37 & 3691.9 & & 0.340 \\
\hline Gneiss (rich in biotite) & 2.37 & 2357.0 & 143.81 & 0.353 \\
\hline Flasergneiss & 4.94 & 4944.0 & 325.94 & 0.940 \\
\hline Flasergneiss & 4.94 & 4936.9 & 563.40 & 0.600 \\
\hline Flasergneiss & 4.94 & 4995.0 & 376.80 & 0.630 \\
\hline Flasergneiss & 4.94 & 488.7 & 469.39 & 0.730 \\
\hline Gneiss & 3.63 & 532.0 & 254.98 & 0.267 \\
\hline Gneiss & 3.63 & 5941.0 & 223.59 & 0.126 \\
\hline Gneiss & 4.70 & & 63.93 & 0.279 \\
\hline Gneiss & 4.70 & & & 0.234 \\
\hline Gneiss & 4.70 & & 7.26 & 0.229 \\
\hline Gneiss & 1.69 & & & 0.494 \\
\hline Gneiss & 1.69 & 3472.0 & 72.45 & 0.443 \\
\hline Gneiss & 3.84 & & & 0.600 \\
\hline Gneiss & 3.30 & & & 0.285 \\
\hline Gneiss & 3.30 & & & 0.332 \\
\hline Gneiss & 4.36 & & & 0.211 \\
\hline Gneiss & 4.36 & & & 0.169 \\
\hline Granite & 2.90 & 3854.3 & 613.69 & 0.480 \\
\hline Granite & 2.90 & 3891.7 & 579.41 & 0.570 \\
\hline Granite & 2.90 & 4155.2 & 552.92 & 0.380 \\
\hline Granite/gneiss & 2.69 & 2248.9 & 185.27 & 0.130 \\
\hline Granite/gneiss & 2.69 & 2111.1 & 416.48 & 0.132 \\
\hline Granite/gneiss & 2.30 & & 123.87 & 0.153 \\
\hline Granite/gneiss & 2.30 & & 169.69 & 0.133 \\
\hline Granite/gneiss & 2.82 & & 31.93 & 0.134 \\
\hline Granite/gneiss & 2.82 & & 311.24 & 0.100 \\
\hline Granite/gneiss & 2.44 & 4255.4 & 233.57 & 0.126 \\
\hline Granite/gneiss & 2.44 & 4261.3 & 188.49 & 0.970 \\
\hline Granite/gneiss (fine grained) & 2.92 & & 124.59 & 0.144 \\
\hline Granite/gneiss (fine grained) & 2.92 & & 127.21 & 0.144 \\
\hline Granite/gneiss (fine grained) & 2.68 & & 115.63 & 0.131 \\
\hline Granite/gneiss (fine grained) & 2.68 & & 243.40 & 0.132 \\
\hline Granite/gneiss (coarse grained) & 2.68 & & 147.78 & 0.165 \\
\hline Granite/gneiss (coarse grained) & 2.55 & & 19.45 & 0.137 \\
\hline Granite & 2.85 & & 72.17 & 0.163 \\
\hline “Knollkopf”-gneiss & 2.68 & 2916.9 & 232.40 & 0.118 \\
\hline “Knollkopf”-gneiss & 2.68 & 2928.8 & 29.29 & 0.150 \\
\hline Migmatit gneiss & 5.90 & 497.8 & 312.29 & 0.520 \\
\hline Migmatit Granite & 2.74 & 455.0 & 349.19 & 0.112 \\
\hline Migmatit Granite & 2.74 & 4495.7 & 22.81 & 0.126 \\
\hline Orthogneiss & 3.16 & 242.9 & 381.89 & 0.117 \\
\hline Orthogneiss & 3.16 & & 286.47 & 0.126 \\
\hline Para(Bi-)gneiss & 2.31 & 3846.7 & 565.77 & 0.870 \\
\hline Para(Bi-)gneiss & 2.31 & 4512.9 & 382.46 & 0.710 \\
\hline Gneiss & 2.63 & & 193.72 & 0.171 \\
\hline Gneiss & 2.63 & & 184.65 & 0.188 \\
\hline
\end{tabular}


Table 3 continued

\begin{tabular}{|c|c|c|c|c|}
\hline Rock type & $\lambda(\mathrm{W} / \mathrm{mK})$ & $v_{\mathrm{p}} \operatorname{dry}(\mathrm{m} / \mathrm{s})$ & $F(-)$ & $\Phi_{\text {eff }}(-)$ \\
\hline Gneiss (rich in quartz) & 3.45 & 3929.1 & 369.78 & 0.650 \\
\hline Gneiss (rich in quartz) & 3.45 & 4393.8 & 35.31 & 0.720 \\
\hline Gneiss (rich in pyrite) & 2.31 & & 185.23 & 0.133 \\
\hline Gneiss (rich in pyrite) & 2.31 & & 19.62 & 0.146 \\
\hline Gneiss & 2.57 & 3442.7 & 239.89 & 0.137 \\
\hline Gneiss & 2.57 & & 185.61 & 0.180 \\
\hline Granite & 2.83 & 5186.9 & 357.48 & 0.830 \\
\hline Granite & 2.83 & 4392.4 & 189.63 & 0.930 \\
\hline Granite & 2.83 & 4647.3 & 52.98 & 0.820 \\
\hline Phyllite (rich in chlorite) & 3.43 & 6477.1 & 124.27 & 0.630 \\
\hline Phyllite (rich in chlorite) & 3.43 & 6138.9 & 127.99 & 0.520 \\
\hline Phyllite (rich in chlorite) & 3.43 & 6276.7 & 133.94 & 0.630 \\
\hline Phyllite (rich in chlorite) & 3.43 & 6232.7 & 124.48 & 0.520 \\
\hline Phyllite (rich in chlorite) & 3.70 & 3986.0 & 313.26 & 0.840 \\
\hline Phyllite (rich in chlorite) & 3.70 & 379.1 & 285.37 & 0.620 \\
\hline Phyllite (rich in chlorite) & 3.70 & 4372.8 & 449.57 & 0.620 \\
\hline Phyllite (rich in chlorite) & 3.70 & 454.2 & 369.77 & 0.640 \\
\hline Phyllite (rich in chlorite) & 4.17 & 5566.7 & 172.26 & 0.520 \\
\hline Phyllite (rich in chlorite) & 4.17 & 499.3 & 11.34 & 0.630 \\
\hline Phyllite (rich in chlorite) & 4.17 & 549.3 & 326.14 & 0.430 \\
\hline Phyllite (rich in chlorite) & 4.17 & 53.5 & 332.33 & 0.420 \\
\hline Phyllite (rich in chlorite) & & 4421.2 & 223.19 & 0.620 \\
\hline Phyllite (rich in chlorite) & & 4134.3 & 118.97 & 0.720 \\
\hline Phyllite (rich in chlorite) & & 4557.6 & 191.49 & 0.720 \\
\hline Phyllite (rich in chlorite) & 3.19 & 5746.0 & 196.20 & 0.470 \\
\hline Phyllite (rich in chlorite) & 3.19 & 5355.0 & 265.33 & 0.490 \\
\hline Phyllite (rich in chlorite) & 3.19 & 5418.8 & 231.29 & 0.590 \\
\hline Phyllite (rich in chlorite) & 3.19 & 533.0 & 177.95 & 0.490 \\
\hline Phyllite (rich in chlorite) & 4.36 & 4866.5 & 183.90 & 0.750 \\
\hline Phyllite (rich in chlorite) & 4.36 & 4965.2 & 197.20 & 0.660 \\
\hline Phyllite (rich in chlorite) & 4.63 & & 94.30 & 0.116 \\
\hline Phyllite (rich in chlorite) & 2.73 & 5483.5 & 236.84 & 0.430 \\
\hline Phyllite (rich in chlorite) & 2.73 & 5335.1 & 435.42 & 0.420 \\
\hline Phyllite (rich in chlorite quartz) & 4.52 & & 295.80 & 0.132 \\
\hline Phyllite (rich in graphite) & 3.60 & 32.9 & 344.75 & 0.780 \\
\hline Phyllite (rich in graphite) & 3.60 & 4787.0 & 376.30 & 0.580 \\
\hline Phyllite (rich in graphite) & 2.88 & 442.0 & 255.28 & 0.970 \\
\hline Phyllite (rich in graphite) & 2.88 & 43.8 & 247.24 & 0.880 \\
\hline Phyllite (rich in graphite) & 3.49 & 5575.9 & 17.25 & 0.880 \\
\hline Phyllite (rich in graphite) & 3.49 & 5112.4 & 17.29 & 0.970 \\
\hline Phyllite (rich in graphite) & 3.49 & 5128.6 & 2.96 & 0.170 \\
\hline Phyllite (rich in graphite) & 3.34 & 566.4 & 12.28 & 0.126 \\
\hline Phyllite (rich in graphite) & 3.34 & 5364.3 & 22.25 & 0.780 \\
\hline Phyllite (rich in graphite) & 3.50 & 321.4 & 343.30 & 0.850 \\
\hline Phyllite (rich in graphite) & 3.50 & 4586.0 & 17.44 & 0.131 \\
\hline Phyllite (rich in graphite) & 3.55 & 426.1 & 151.10 & 0.900 \\
\hline Phyllite (rich in graphite) & 3.55 & & 193.11 & 0.890 \\
\hline Phyllite (rich in graphite) & 3.55 & 4334.7 & 239.84 & 0.880 \\
\hline
\end{tabular}


Table 3 continued

\begin{tabular}{|c|c|c|c|c|}
\hline Rock type & $\lambda(\mathrm{W} / \mathrm{mK})$ & $v_{\mathrm{p}} \operatorname{dry}(\mathrm{m} / \mathrm{s})$ & $F(-)$ & $\Phi_{\text {eff }}(-)$ \\
\hline Phyllite (rich in graphite) & 2.96 & 3437.3 & 227.19 & 0.980 \\
\hline Phyllite (rich in graphite) & 2.96 & 451.5 & 33.22 & 0.790 \\
\hline Phyllite (rich in graphite) & 2.96 & 468.6 & 22.50 & 0.780 \\
\hline Phyllite & 2.81 & 3956.6 & 85.27 & 0.197 \\
\hline Phyllite & 3.00 & & 281.50 & 0.143 \\
\hline Phyllite & 3.00 & & 212.20 & 0.168 \\
\hline Phyllite & 2.97 & & 125.30 & 0.950 \\
\hline Phyllite & 2.97 & 5252.6 & 114.99 & 0.190 \\
\hline Phyllite & 2.97 & 4911.3 & 192.34 & 0.860 \\
\hline Phyllite & 2.53 & 4427.0 & 176.90 & 0.970 \\
\hline Phyllite & 2.53 & 5627.8 & 14.37 & 0.110 \\
\hline Phyllite & 3.70 & 453.0 & 186.30 & 0.800 \\
\hline Phyllite & 3.70 & 499.6 & 28.80 & 0.790 \\
\hline Phyllite & 3.70 & 4914.4 & 184.62 & 0.790 \\
\hline Phyllite & 3.70 & 4626.1 & 196.93 & 0.790 \\
\hline Phyllite & 2.80 & 459.9 & 134.16 & 0.790 \\
\hline Phyllite & 2.80 & 4525.5 & 133.21 & 0.100 \\
\hline Phyllite & 3.52 & & 158.65 & 0.170 \\
\hline Phyllite & 3.88 & 66.1 & 189.33 & 0.730 \\
\hline Phyllite & 3.88 & 5115.4 & 191.82 & 0.120 \\
\hline Phyllite & 3.88 & 5931.1 & 21.53 & 0.130 \\
\hline Phyllite & 3.36 & 5163.2 & 187.10 & 0.113 \\
\hline Phyllite & 3.36 & 4972.6 & 191.24 & 0.920 \\
\hline Phyllite & 3.36 & 4758.3 & 232.64 & 0.710 \\
\hline Phyllite & 3.36 & & 158.44 & 0.920 \\
\hline Black phyllite/quarzite & & 4338.8 & 147.73 & 0.580 \\
\hline Black phyllite/quarzite & & & 96.45 & 0.940 \\
\hline Black phyllite/quarzite & & & 133.64 & 0.770 \\
\hline Green phyllite (rich in anhydrite) & 5.42 & 2673.0 & 43.83 & \\
\hline Mica schist (rich in biotite) & 2.72 & 3171.7 & 584.12 & 0.470 \\
\hline Mica schist (rich in biotite) & 2.72 & 4135.8 & 511.14 & 0.580 \\
\hline Mica schist (rich in chlorite) & 3.28 & 5222.0 & 557.18 & 0.520 \\
\hline Mica schist (rich in chlorite) & 3.28 & 5275.1 & 56.69 & 0.740 \\
\hline Mica schist (rich in chlorite) & 3.28 & 573.2 & 422.61 & 0.620 \\
\hline Mica schist & 3.66 & & 111.99 & 0.240 \\
\hline Mica schist & 3.54 & & & 0.133 \\
\hline Mica schist & 3.38 & 498.9 & 41.72 & 0.520 \\
\hline Mica schist & 3.38 & 5165.8 & 282.90 & 0.510 \\
\hline Mica schist & 3.38 & 535.4 & 381.51 & 0.410 \\
\hline Mica schist & 3.38 & 5385.9 & 535.26 & 0.620 \\
\hline Mica schist & 2.94 & 4975.2 & 239.91 & 0.510 \\
\hline Mica schist & 2.94 & 493.7 & 267.40 & 0.510 \\
\hline Mica schist & 2.94 & 481.7 & 262.46 & 0.510 \\
\hline Mica schist & 2.94 & 492.4 & 282.96 & 0.520 \\
\hline Mica schist & 5.46 & 3995.9 & 276.60 & 0.740 \\
\hline Mica schist & 5.46 & 649.1 & 168.70 & 0.960 \\
\hline Mica schist & 4.54 & 4588.8 & 267.39 & 0.620 \\
\hline Mica schist & 4.54 & 4694.8 & 362.56 & 0.510 \\
\hline
\end{tabular}


Table 3 continued

\begin{tabular}{|c|c|c|c|c|}
\hline Rock type & $\lambda(\mathrm{W} / \mathrm{mK})$ & $v_{\mathrm{p}} \operatorname{dry}(\mathrm{m} / \mathrm{s})$ & $F(-)$ & $\Phi_{\text {eff }}(-)$ \\
\hline Mica schist & 4.54 & 4775.6 & 281.46 & 0.530 \\
\hline Mica schist & 5.98 & 4199.6 & 314.50 & 0.590 \\
\hline Mica schist & 5.98 & 4149.2 & 294.88 & 0.680 \\
\hline Mica schist & 5.98 & 4196.9 & 53.85 & 0.570 \\
\hline Mica schist & 5.98 & 436.1 & 335.35 & 0.580 \\
\hline Mica schist & 4.45 & 5775.7 & 38.43 & 0.380 \\
\hline Mica schist & 4.45 & 5248.8 & 457.60 & 0.480 \\
\hline Mica schist & 4.45 & 5668.4 & 323.81 & 0.390 \\
\hline Mica schist & 4.45 & 577.0 & 347.89 & 0.390 \\
\hline Mica schist & 4.45 & 566.2 & 427.64 & 0.280 \\
\hline Mica schist & 4.45 & 5111.1 & 464.14 & 0.390 \\
\hline Mica schist & 4.45 & 65.6 & 816.42 & 0.390 \\
\hline Mica schist & 4.45 & 5628.3 & 53.32 & 0.390 \\
\hline Mica schist & 3.29 & 4995.3 & 278.85 & 0.390 \\
\hline Mica schist & 3.29 & 4245.0 & 447.93 & 0.780 \\
\hline Mica schist & 2.49 & 5636.4 & 278.23 & 0.720 \\
\hline Mica schist & 2.49 & 535.3 & 286.22 & 0.510 \\
\hline Mica schist & 2.49 & 5576.3 & 36.63 & 0.610 \\
\hline Mica schist & 2.49 & 5111.4 & 314.88 & 0.620 \\
\hline Mica schist & 3.63 & 4188.5 & 188.57 & 0.111 \\
\hline Mica schist & 3.63 & 3292.4 & 165.80 & 0.134 \\
\hline Mica schist (rich in chlorite) & 2.79 & 4898.5 & 212.90 & 0.420 \\
\hline Mica schist (rich in chlorite) & 2.79 & 4922.1 & 321.16 & 0.420 \\
\hline Mica schist (rich in chlorite) & 2.79 & 4792.7 & 267.46 & 0.420 \\
\hline Mica schist (rich in chlorite) & 2.86 & 4392.4 & 242.60 & 0.600 \\
\hline Mica schist (rich in chlorite) & 2.86 & 3851.1 & 224.18 & 0.800 \\
\hline Mica schist (rich in chlorite) & 2.86 & 4382.2 & 227.72 & 0.590 \\
\hline Mica schist (rich in garnet) & 3.90 & 666.4 & 64.18 & 0.290 \\
\hline Mica schist (rich in garnet) & 3.90 & 6533.7 & 725.86 & 0.270 \\
\hline Mica schist (rich in garnet) & 3.90 & 5669.0 & 547.86 & 0.350 \\
\hline Mica schist (rich in garnet) & 4.70 & 598.8 & 356.80 & 0.360 \\
\hline Mica schist (rich in garnet) & 4.70 & 5892.9 & 867.23 & 0.460 \\
\hline Mica schist (rich in garnet) & 4.70 & 5946.6 & 634.71 & 0.270 \\
\hline Mica schist (rich in garnet) & 4.79 & & 613.41 & 0.450 \\
\hline Mica schist (rich in garnet) & 4.79 & & & 0.470 \\
\hline Green schist & & 482.8 & 166.35 & 0.860 \\
\hline Green schist & & 5436.2 & 171.31 & 0.170 \\
\hline Green schist & & 5353.9 & 157.14 & 0.980 \\
\hline Green schist & & 579.1 & 144.43 & 0.116 \\
\hline Mica schist (rich in quartz) & 4.22 & 4474.8 & 36.46 & 0.860 \\
\hline Mica schist (rich in quartz) & 3.13 & 5218.7 & 219.56 & 0.740 \\
\hline Mica schist (rich in quartz) & 3.13 & 4987.4 & 239.95 & 0.740 \\
\hline Mica schist (rich in quartz) & 3.13 & 431.7 & 117.59 & 0.159 \\
\hline Mica schist (rich in quartz) & 3.53 & 416.9 & 182.75 & 0.160 \\
\hline Mica schist (rich in quartz) & 3.53 & 4652.8 & 231.41 & 0.770 \\
\hline Mica schist (rich in quartz) & 3.53 & 447.8 & 235.13 & 0.680 \\
\hline Mica schist (rich in quartz) & 3.53 & 4597.0 & 179.92 & 0.116 \\
\hline Mica schist (rich in $\mathrm{Ca}$ ) & 2.30 & 491.5 & 12.79 & 0.630 \\
\hline
\end{tabular}


Table 3 continued

\begin{tabular}{|c|c|c|c|c|}
\hline Rock type & $\lambda(\mathrm{W} / \mathrm{mK})$ & $v_{\mathrm{p}} \operatorname{dry}(\mathrm{m} / \mathrm{s})$ & $F(-)$ & $\Phi_{\text {eff }}(-)$ \\
\hline Mica schist (rich in $\mathrm{Ca}$ ) & 2.30 & 4972.6 & 111.40 & 0.127 \\
\hline Mica schist (rich in $\mathrm{Ca}$ ) & 2.30 & 5148.4 & 125.95 & 0.640 \\
\hline Mica schist & 3.33 & & 283.40 & 0.950 \\
\hline Mica schist & 3.45 & 2941.9 & 334.74 & 0.161 \\
\hline Mica schist & 3.45 & 213.0 & 36.18 & 0.280 \\
\hline Mica schist (rich in quartz) & 4.65 & 3554.0 & 337.12 & 0.187 \\
\hline Mica schist (rich in quartz) & 4.65 & 3449.8 & 248.32 & 0.168 \\
\hline Mica schist (rich in quartz) & 4.65 & 3755.5 & 452.41 & 0.144 \\
\hline Mica schist (rich in quartz) & 3.83 & 4529.5 & 252.87 & 0.270 \\
\hline Mica schist (rich in quartz) & 3.83 & 4615.0 & 257.60 & 0.140 \\
\hline Mica schist (rich in quartz) & 3.83 & 4714.6 & 252.64 & 0.145 \\
\hline Mica schist & 2.85 & 3811.0 & 162.73 & 0.398 \\
\hline Mica schist & 2.85 & 3727.1 & 127.36 & 0.438 \\
\hline Mica schist & 2.85 & 393.5 & 221.98 & 0.252 \\
\hline Mica schist & 2.85 & 379.3 & 82.87 & 0.477 \\
\hline Mica schist & 3.33 & & 423.73 & 0.152 \\
\hline Metaarenite & 3.58 & 552.6 & 312.12 & 0.300 \\
\hline Metaarenite & 3.58 & 5533.7 & 287.34 & 0.290 \\
\hline Metaarenite & 3.58 & 5421.3 & 245.53 & 0.390 \\
\hline Metaarenite & 3.64 & 5216.7 & 239.72 & 0.390 \\
\hline Metaarenite & 3.64 & 5263.7 & 234.86 & 0.490 \\
\hline Metaarenite & 3.64 & 5449.2 & 33.67 & 0.390 \\
\hline Metaarenite & 3.64 & 5346.7 & 228.36 & 0.490 \\
\hline Metaarenite & 3.43 & 518.2 & 286.72 & 0.840 \\
\hline Metaarenite & 3.43 & 4748.8 & 239.28 & 0.530 \\
\hline Metaarenite & 3.43 & 589.3 & 191.92 & 0.730 \\
\hline Metaarenite & 3.38 & 578.9 & 244.00 & 0.490 \\
\hline Metaarenite & 3.38 & 533.2 & 234.84 & 0.490 \\
\hline Metaarenite & 3.38 & 526.3 & 24.74 & 0.490 \\
\hline Metaarenite & 3.38 & 4912.4 & 231.11 & 0.690 \\
\hline Metaarenite & 4.30 & 68.5 & 61.56 & 0.190 \\
\hline Metaarenite & 4.30 & 5531.3 & 139.60 & 0.690 \\
\hline Metaarenite & 4.30 & 5725.8 & 13.96 & 0.990 \\
\hline Metaarenite & 4.30 & 588.7 & 87.86 & 0.980 \\
\hline Metaarenite & 4.74 & 4822.7 & 173.69 & 0.690 \\
\hline Metaarenite & 4.74 & 5178.7 & 132.96 & 0.790 \\
\hline Metaarenite & 4.74 & 5629.6 & 74.31 & 0.900 \\
\hline Metaarenite & 4.74 & & 139.34 & 0.790 \\
\hline Metaarenite & 6.80 & 4635.5 & 324.80 & 0.530 \\
\hline Metaarenite & 6.80 & 4683.3 & 448.93 & 0.540 \\
\hline Metaarenite & 6.80 & 4863.9 & 353.85 & 0.530 \\
\hline Metaarenite & 3.51 & 4666.7 & 36.63 & 0.530 \\
\hline Metaarenite & 3.51 & 4815.5 & 335.81 & 0.530 \\
\hline Metaarenite & 3.51 & 4876.8 & 374.50 & 0.630 \\
\hline Metaarenite & 4.26 & 4938.1 & 37.13 & 0.420 \\
\hline Metaarenite & 4.26 & 545.7 & 391.93 & 0.630 \\
\hline Metaarenite & 4.26 & 4857.8 & 448.16 & 0.420 \\
\hline Metaarenite & 4.26 & 4923.6 & 3.64 & 0.530 \\
\hline
\end{tabular}


Table 3 continued

\begin{tabular}{|c|c|c|c|c|}
\hline Rock type & $\lambda(\mathrm{W} / \mathrm{mK})$ & $v_{\mathrm{p}} \operatorname{dry}(\mathrm{m} / \mathrm{s})$ & $F(-)$ & $\Phi_{\text {eff }}(-)$ \\
\hline Metaarenite & 3.24 & 517.7 & 333.84 & 0.530 \\
\hline Metaarenite & 3.24 & 491.2 & 375.60 & 0.530 \\
\hline Metaarenite & 3.24 & 4731.1 & 339.39 & 0.630 \\
\hline Metaarenite & 3.24 & 4729.9 & 31.40 & 0.640 \\
\hline Sandstone & 2.18 & 1887.7 & 46.98 & 0.1141 \\
\hline Quarzite & 4.60 & 5464.5 & 261.90 & 0.186 \\
\hline Quarzite & 4.60 & 5484.5 & 265.99 & 0.178 \\
\hline Quarzite & 4.60 & 5484.5 & 259.40 & 0.151 \\
\hline Quarzite & 4.60 & 55.0 & 331.90 & 0.151 \\
\hline Metaarenite & 3.51 & 494.3 & 314.72 & 0.221 \\
\hline Sandstone (with clay. marl) & 2.27 & 2759.2 & 7.61 & 0.752 \\
\hline Sandstone (with clay. marl) & 2.27 & 321.0 & 78.94 & 0.688 \\
\hline Sandstone (with clay. marl) & 2.27 & 31.0 & 78.90 & 0.693 \\
\hline Sandstone (with clay. marl) & 2.10 & 4271.0 & 96.20 & 0.726 \\
\hline Sandstone (with clay. marl) & 2.10 & 4277.6 & 86.75 & 0.734 \\
\hline Sandstone (with clay. marl) & 2.10 & 4315.6 & 85.77 & 0.740 \\
\hline Metabasalt & 2.40 & 4614.0 & 13.21 & 0.125 \\
\hline Metabasalt & 2.40 & 4564.2 & 92.50 & 0.127 \\
\hline Metabasalt & 2.40 & 4571.1 & 18.50 & 0.125 \\
\hline Metabasite & 3.19 & 5173.6 & 151.82 & 0.730 \\
\hline Metabasit & 3.19 & 494.6 & 166.48 & 0.720 \\
\hline Metabasit & 3.19 & 5192.9 & 165.67 & 0.860 \\
\hline Metabasit & 2.68 & 5298.9 & 137.49 & 0.730 \\
\hline Metabasit & 2.68 & 5144.3 & 152.86 & 0.730 \\
\hline Metabasit & 2.68 & 563.5 & 147.17 & 0.830 \\
\hline Metabasit & 2.82 & 439.0 & 156.30 & 0.880 \\
\hline Metabasit & 2.82 & 4292.3 & 144.25 & 0.970 \\
\hline Metabasit & 2.82 & 434.8 & 157.77 & 0.970 \\
\hline Metabasit & 1.72 & 4568.8 & 91.96 & 0.147 \\
\hline Metabasit & 1.72 & 4473.1 & 94.83 & 0.147 \\
\hline Metabasit & 1.72 & 455.2 & 78.53 & 0.157 \\
\hline Metabasit & 3.80 & 2979.1 & 171.78 & 0.880 \\
\hline Metabasit & 3.80 & 359.9 & 27.40 & 0.880 \\
\hline Metabasit & 4.37 & 45.7 & 149.34 & 0.158 \\
\hline Metabasit & 4.37 & 4158.2 & 168.27 & 0.120 \\
\hline Metabasit & 4.37 & 5218.1 & 173.5 & 0.128 \\
\hline
\end{tabular}

\section{References}

Abdulagatova Z, Abdulagatov IM, Emirov VN (2009) Effect of temperature and pressure on the thermal conductivity of sandstone. Int J Rock Mech Min Sci 46:1055-1071. doi:10. 1016/j.ijrmms.2009.04.011

Archie G (1942) The electrical resistivity log as an aid in determining some reservoir characteristics. Trans Am Inst Min Metal Eng 146:54-62

Barry-Macaulay D, Bouazza A, Singh RM, Wang B, Ranjith PG (2013) Thermal conductivity of soils and rocks from the Melbourne (Australia) region. Eng Geol 164:131-138. doi:10. 1016/j.enggeo.2013.06.014
Berryman JG (1995) Mixture theories for rock properties. In: Ahrens TJ (ed) Rock physics and phase relations: a handbook of physical constants. Am Geophys Union Washington, DC. 205-228, doi:10.1029/RF003p0205

Budiansky B, O'Connell RJ (1976) Elastic moduli of a cracked solid. Int J Solids Struct 12:81-97

Fuchs S (2013) Well-log based determination of rock thermal conductivity in the North German Basin, PhD thesis. University Potsdam, Germany

Fuchs S, Balling N, Foerster A (2015) Calculation of thermal conductivity, thermal diffusivity and specific heat capacity of sedimentary rocks using petrophysical well logs. Geophys J Int 203:1977-2000. doi:10.1093/gji/ggv403 
Gąsior I, Przelaskowska A (2014) Estimating thermal conductivity from core and well log data. Acta Geophys 62(4):785-801. doi:10.2478/s11600-014-0204-y

Gegenhuber N, Schön J (2012) New approaches for the relationship between compressional wave velocity and thermal conductivity. J Appl Geophys 76:50-55. doi:10.1016/j.jappgeo.2011.10.005

Gegenhuber N, Steiner-Luckabauer C (2012) Vp/Vs automatic picking of ultrasonic measurements and their correlation of petrographic coded carbonates from Austria. In: 74th EAGE conference and exhibition, Copenhagen, Denmark

Hartmann A, Rath V, Clauser C (2005) Thermal conductivity from core and well log data. Int $J$ Rock Mech Min Sci 42(7-8):1042-1055. doi:10.1016/j.ijrmms.2005.05.015

Kukkonen IT, Peltioniemi S (1998) Relationship between thermal and other petrophysical properties of rocks of Finland. Phys Chem Earth 23:341-349

Lichtenecker K (1924) Der elektrische Leitunswiderstand künstlicher und natürlicher Aggregate. Physikal Zeitsch 25(8):169-233
Oezkahraman HT, Selver R, Işık EC (2004) Determination of the thermal conductivity of rock from P-wave velocity. Int J Rock Mech Min Sci 41(4):703-708. doi:10.4236/gm.2013.34018

Popov Y, Tertchnyi V, Romushkevich R, Korobkov D, Pohl J (2003) Interrelations between thermal conductivity and other physical properties of rocks: experimental data. Pure Appl Geophys 160:1137-1161

Schoen JH (2011) Physical properties of rocks: a workbook, handbook of petroleum exploration and production, vol 8 . Elsevier, Amsterdam

Schoen JH (2015) Physical properties of rocks: fundamentals and principles of petrophysics, developments in petroleum science, vol 65. Elsevier, Amsterdam

Sundberg J, Back P-E, Ericsson LO, Wrafter J (2009) Estimation of thermal conductivity and its spatial variability in igneous rocks from in situ density logging. Int $J$ Rock Mech Min Sci 46(6):1023-1028. doi:10.1016/j.ijrmms.2009.01.010 